\title{
Assemblages of Gelatinous Zooplankton in Mesoscale Oceanographic Features in the Tropical- Temperate Transition Zone of a Western Boundary Current
}

Kylie Pitt ( $\sim$ K.Pitt@griffith.edu.au )

Griffith University https://orcid.org/0000-0002-2292-2052

Jonathan W. Lawley

Griffith University

Charles Hinchliffe

University of New South Wales

Paloma A. Matis

University of New South Wales

lain M. Suthers

University of New South Wales

\section{Research Article}

Keywords: Gelatinous Zooplankton, Oceanographic, Boundary Current

Posted Date: April 19th, 2021

DOI: https://doi.org/10.21203/rs.3.rs-406951/v1

License: (c) (1) This work is licensed under a Creative Commons Attribution 4.0 International License.

Read Full License 


\section{Abstract}

Boundary currents generate cyclonic and anticyclonic eddies, which strongly influence the composition of plankton communities and their spatial dynamics. We explored the gelatinous zooplankton communities where the East Australian Current (EAC) intensifies between $25-31^{\circ} \mathrm{S}$, forming a dynamic eddy field at a tropical/temperate boundary. Five types of mesoscale features including the EAC were sampled: the adjacent continental shelf, a transient upwelling feature at the shelf break, a cyclonic frontal eddy which had entrained shelf water and a larger cyclonic eddy that had originated in the Tasman Sea. Forty-two gelatinous taxa were sampled from 62 plankton tows, including 24 cnidarians ( 9 hydromedusae, 14 siphonophores, 1 scyphozoan), 5 ctenophores and 12 thaliaceans. Assemblages of gelatinous zooplankton differed significantly among oceanographic features but were dominated by the salp, Salpa fusiformis, which comprised $66 \%$ of the overall catch. Abundances of gelatinous zooplankton were lowest in the EAC, the shelf break upwelling feature and over the continental shelf, which at the time sampled was flooded by a coastal incursion of the EAC. Abundances were greatest in the two cyclonic eddies and increased four-fold in the Tasman Sea cyclonic eddy over the three times it was sampled, highlighting the importance of cyclonic eddies in driving production of gelatinous zooplankton.

\section{Introduction}

Gelatinous zooplankton, including cnidarian medusae and siphonophores, ctenophores and thaliaceans comprise a large component of the pelagic zooplankton biomass (Lucas et al. 2014; Wright RM 2021). Their unique, watery body plans facilitate high clearance and growth rates (Acuna et al. 2011; Pitt et al. 2013), which enables their populations to flourish when food is abundant. Gelatinous zooplankton are increasingly being recognised as significant food sources for a diverse range of pelagic predators (Hays et al. 2018) and as critical components of the biological pump (Condon et al. 2011; Luo et al. 2020; Wright RM 2021). Indeed, gelatinous zooplankton may contribute up to $40 \%$ of global particulate organic carbon export through sinking of their fecal pellets and carcasses (Luo et al. 2020). Given their ability to respond rapidly to increases in primary production, oceanographic features that promote upwelling, such as cyclonic eddies, may drive regional-scale increases in gelatinous zooplankton. For example, the pyrosome Pyrosoma atlanticum, was two-orders of magnitude more abundant in a cold core eddy than in warm core eddies in the Tasman Sea (Henschke et al. 2019) and the greatest density of salps ever recorded, similarly occurred in a cold core eddy (Everett et al. 2011). Knowledge of the dynamics and drivers of gelatinous zooplankton populations is thus critical for understanding pelagic food webs and global biogeochemical cycles.

Western boundary currents (WBCs) are the most energetic currents in the ocean. They transport warm, tropical waters polewards and strongly influence regional climate (Sprintall et al. 1995) and fisheries (Hofmann and Powell 1998; Suthers et al. 2011; Young et al. 2011). Although the poleward jet of a WBC is the predominant feature, current meanders, local topography and changes in current velocities and trajectories create instabilities that produce distinct meso-scale oceanographic features. These include cyclonic (upwelling) and anti-cyclonic (downwelling) eddies and frontal eddies that form by instabilities 
or when the coastal edge of a WBC intercepts prominent headlands (Ismail et al. 2017). Acceleration of flow and divergence of water masses can also generate regions of upwelled, cool and nutrient rich water (e.g. (Everett et al. 2014). These different mesoscale features strongly influence primary production (Everett et al. 2014), support different biological communities and may have a major influence on regional plankton dynamics (Henschke et al. 2015), including production of gelatinous zooplankton e.g. (Pagés et al. 2001; Riandey et al. 2005).

The East Australian Current (EAC) is the western boundary current of the South Pacific Gyre and is the dominant oceanographic feature along Australia's east coast (Suthers et al. 2011). The EAC originates between $15^{\circ} \mathrm{S}$ and $20^{\circ} \mathrm{S}$ from the southern bifurcation of the South Equatorial Current (Ridgway and Dunn 2003). The current nears the coast and intensifies as it flows around the most easterly section of the Australian continent between $23^{\circ} \mathrm{S}$ and $31^{\circ} \mathrm{S}$, after which it slows and separates into easterly and southerly flows (but see (Oke et al. 2019)). South of the separation zone, the EAC generates complex fields of cyclonic and anti-cyclonic eddies (Ridgway and Dunn 2003; Everett et al. 2012) that support production and cross shelf transport of commercially important fish larvae e.g. (Mullaney et al. 2011; Matis et al. 2014; Malan et al. 2020) and drive production of huge blooms of pyrosomes and salps e.g. (Everett et al. 2011; Henschke et al. 2014). Although the EAC south of the separation zone has been reasonably well-studied, the biology of the northern intensification zone has received minimal attention. This is surprising, as this region at the tropical/temperate boundary, is at the forefront of range expansions by tropical species (e.g. Armbrecht et al. 2015) and sustains important pelagic fisheries (Revill et al. 2009; Young et al. 2011). Studies of planktonic communities in the intensification zone have been limited to shelf waters, including studying changes in phytoplankton communities among seasons (Armbrecht et al. 2015; Ribbe and Brieva 2016) and during upwelling and downwelling events (Armbrecht et al. 2014).

This study aimed to understand the relationship between mesoscale oceanographic features and assemblages of gelatinous zooplankton in the intensification zone of the EAC. Gelatinous zooplankton assemblages were compared between the EAC jet and over the inshore continental shelf, and among different types of cyclonic eddies and associated features. We also examined the production and maturation of a gelatinous zooplankton community by sampling a cyclonic eddy three times over eight days. We hypothesised that mesoscale features would host different gelatinous assemblages; that cyclonic eddies would support the greatest concentrations of gelatinous zooplankton; and that concentrations of gelatinous zooplankton would increase over time in a cyclonic eddy.

\section{Methods}

\section{Study area}

The study focused on the central region of the intensification zone, where the EAC is most coherent, between $27.025^{\circ} \mathrm{S}$ and $27.955^{\circ} \mathrm{S}$ and $155.341^{\circ} \mathrm{E}$ and $153.611^{\circ} \mathrm{E}$. The study area coincided with an oceanographic mooring array that monitors the dynamics of the EAC and extends across the continental 
shelf to the abyssal plain at $27^{\circ} \mathrm{S}$ (Sloyan et al. 2016). The region is dominated by the seasonally recurring Fraser Gyre that extends over the continental shelf from approximately $25^{\circ} \mathrm{S}-27^{\circ} \mathrm{S}$ and forms during the austral autumn and winter (Ismail et al. 2017). During spring and summer, periodic upwelling occurs, associated with current-driven bottom stress (referred to as the Southeast Fraser Island Upwelling System; Brieva et al. 2015) creating a key marine ecological site (Ribbe and Brieva 2016). The region close to the coast (i.e. within $100 \mathrm{~km}$ ) is a 'hot spot' for short-lived (7-28 days) eddies with over $40 \%$ of all short-lived eddies in the EAC occurring in this region (Ribbe \& Brieva 2016). Smaller cyclonic frontal eddies also form when the western edge of the EAC intercepts prominent headlands on Fraser Island at $25^{\circ} \mathrm{S}$ (Ribbe et al. 2018). Cyclonic mesoscale and frontal eddies can entrain coastal water and generate near-shore northward flows (Brieva et al. 2015; Ribbe \& Brieva 2016).

\section{Sampling of gelatinous zooplankton}

Gelatinous zooplankton were sampled during the austral spring, between Sept $11^{\text {th }}$ and $27^{\text {th }} 2019$ during a voyage on $R V$ Investigator. Diel vertical migration is a common behaviour of many gelatinous zooplankton including pyrosomes (Andersen and Sardou 1994; Henschke et al. 2019) and salps (e.g. Wiebe et al. 1979) and these taxa are typically more abundant in surface waters at night. Sampling commenced at least an hour after sunset and concluded more than one hour before sunrise (18:54 - 4:00 AEST) to minimise any confounding effects due to variable vertical distributions. Replicate plankton samples were collected at nine locations within five different oceanographic features (Table 1; Fig. 1), including two locations within the EAC jet (EAC-1; EAC-2), two locations over the inshore continental shelf (Shelf-1; Shelf-2); within a transient upwelling zone (shelf break upwelling) and within two cyclonic eddies; a frontal eddy and a Tasman Sea cyclonic eddy that was sampled three times over eight days.

Plankton was sampled using a bongo net (mouth diameter: $0.7 \mathrm{~m}$; mesh size: $500 \mu \mathrm{m}$ ) fitted with a mechanical flow meter (General Oceanics, Florida, USA). The net was towed obliquely in a profile that extended from the surface to $43 \mathrm{~m}( \pm 7.1 \mathrm{~m} \mathrm{SD})$ and back to the surface. Tow duration ranged from 13-19 minutes (mean=16), tow speed ranged from 1 to $1.5 \mathrm{~ms}^{-1}$, and the average volume sampled was $693 \mathrm{~m}^{3}$ $\left( \pm 256 \mathrm{~m}^{3} \mathrm{SD}\right)$. Samples were immediately preserved in $5 \%$ formalin.

Gelatinous zooplankton, including cnidarian medusae, siphonophores, ctenophores and thaliaceans were separated from non-gelatinous zooplankton to be identified and enumerated. Colonies of siphonophores were generally disaggregated into zooids and were recorded as presence/absence only. Aggregate and solitary forms of salps were counted separately and pyrosomes were counted as entire colonies. Gelatinous zooplankton were identified to species or genus except for doliolids, which were aggregated into Order Doliolida because many were damaged and could not be identified to narrower taxonomic categories. Abundances were standardised to concentrations (individuals $\mathrm{m}^{-3}$ ). An index of production of the most abundant salp, Salpa fusiformis, was created using the ratio of aggregate to solitary stages, based on the expectation that a greater proportion of aggregates would occur in a rapidly growing population (Foxton 1966; Henschke \& Pakhomov 2018). 


\section{Zooplankton}

Zooplankton (including gelatinous and non-gelatinous taxa) were sampled using a $100 \mu \mathrm{m}$ mesh, $0.2 \mathrm{~m}$ diameter ring net that was mounted within the bongo net. Zooplankton were immediately fixed in $5 \%$ formalin and counted in the laboratory using a Laser Optical Plankton Counter (LOPC, Rolls Royce Canada Ltd., Canada) that counted particles ranging in size from 200 to $30000 \mu \mathrm{m}$ (Herman et al. 2004).

\section{Physical oceanography}

Temperature, salinity and fluorescence were recorded during each bongo net tow using a Sea-Bird-SBE 21 thermosalinograph (Sea-Bird Scientific, USA) and fluorometer (WETStar, WETLabs, USA) that sampled underway seawater collected from a drop keel $4 \mathrm{~m}$ below the hull at 1 second intervals. Fluorescence units (V) were converted to chlorophyll $a$ (chl a) concentrations using the manufacturer's calibration, which used a liquid fluorescent standard and reference fluorometer whose chlorophyll fluorescence response was characterised using a culture of the diatom Thallassiosira weissflogii (WETLabs). Chl a concentrations were halved, to account for a calibration bias of 2, established for WET Labs ECO-series fluorometers (Roesler et al. 2017). Bathymetric depths of each tow were derived values from GEBCO 15 arc-second Grid (IOC et al. 2003). All instruments were calibrated at the CSIRO Calibration Facility in Hobart.

\section{Statistical analyses}

Variation in concentrations (excluding siphonophores), taxon-richness (including siphonophores) and gelatinous zooplankton assemblages (excluding siphonophores) among the nine locations was analysed using one-way nonparametric permutational ANOVAs (PERMANOVA); (Anderson 2001). Data were square-root transformed and the resemblance matrices constructed using Bray-Curtis similarity. Pair-wise comparisons were used to identify which features differed and the three taxa that contributed the most to dissimilarity among pairs of features were identified using SIMPER. A distance-based linear model (DistLM) quantified how much of the variation in gelatinous zooplankton assemblages was explained by temperature, salinity, chl $a$, and bathymetric depth. Environmental data were normalised and a resemblance matrix constructed using Euclidian distance. A step-wise selection procedure was used to determine the combination of predictor variables that best explained variation in gelatinous zooplankton assemblages. The best fitting model was determined using the AICc selection criterion. A distance-based redundancy analysis (dbRDA) ordination was used to visualise differences in gelatinous zooplankton assemblages and the predictor variables that explained the most variation in gelatinous zooplankton assemblages.

Univariate analyses of concentrations of total gelatinous zooplankton (excluding siphonophores), taxon richness (including siphonophores), total zooplankton (as measured using the LOPC) and individual species of gelatinous zooplankton highlighted by SIMPER as driving differences among features were analysed using one-way PERMANOVAs on square-root transformed data. Resemblance matrices were constructed using the zero-adjusted Bray-Curtis dissimilarity metric (Clarke et al. 2006). 
Assemblages of siphonophores among oceanographic features were analysed separately using a oneway PERMANOVA. Data were transformed to presence/absence and a dissimilarity matrix was constructed based on Bray-Curtis similarity and assemblages visualised using PCO. Pair-wise PERMANOVA was used to identify features that differed and SIMPER was used to identify the three taxa that contributed most to the dissimilarity among features.

\section{Results}

\section{Regional oceanography}

The Tasman Sea cyclonic eddy dominated the region for the 22-day voyage (Fig. 1). The Tasman Sea cyclonic eddy formed from the easterly divergence of the EAC approximately a month prior to sampling. Temperature increased by $>0.5^{\circ} \mathrm{C}$ and chl a concentrations halved over the three occasions ( 8 days) the Tasman Sea cyclonic eddy was sampled. At the start of the voyage, the warm EAC jet was situated offshore (Fig. 1) and concentrations of chl a at EAC-1 were double those at EAC-2 (Table 1). The frontal eddy formed on approximately $12 / 9 / 2019$, six days prior to sampling when the western edge of the EAC intercepted Fraser Island. The frontal eddy entrained shelf water (Fig. 1) and was characterised by intermediate values of temperature, salinity and chl $a$ (Table 1). The shelf break upwelling was a transient feature that formed at the shelf break 1-2 days before sampling, driven by the eastward flow of EAC to the north and the eastward flow of the Tasman Sea cyclonic eddy to the south. It was $0.6-1.1^{\circ} \mathrm{C}$ cooler and more saline than any other feature sampled, with relatively high values of $\mathrm{chl} a$, indicative of upwelling.

And the end of the voyage, shelf waters were sampled twice and both occasions coincided with a transient incursion of the EAC onto the shelf, as characterised by temperatures at the shelf locations being $\sim 0.5^{\circ} \mathrm{C}$ warmer at the end of the voyage compared to the beginning (Fig. 1). CTD casts indicated the EAC water occupied the upper $25 \mathrm{~m}$ of the water column, with a sharp thermocline demarcating the EAC water from the cooler shelf water below. SST was slightly $\left(\sim 0.3^{\circ} \mathrm{C}\right)$ cooler and chl a concentrations were marginally higher at Shelf-2 than at Shelf-1 indicating that the EAC incursion may have been greater at Shelf-1. Overall, chl a concentrations were low $\left(<0.25 \mu \mathrm{g} \mathrm{L}^{-1}\right)$, even in the upwelling features and variations in salinity were small (range $35.59-35.72$; Table 1 ).

\section{Gelatinous zooplankton assemblages}

Forty-two taxa of gelatinous zooplankton were sampled, including 24 cnidarians ( 9 hydromedusae, 14 siphonophores, 1 scyphozoan), 5 ctenophores and 12 thaliaceans. Catches of cnidarians (excluding siphonophores) and ctenophores were negligible, with thaliaceans comprising almost $99 \%$ of the total catch. Salpa fusiformis, was the most abundant taxon and contributed $66 \%$ of the overall catch. Taxon richness (including siphonophores) did not vary among locations (Pseudo- $\mathrm{F}=2.0438 ; P=0.052$; mean=14.2, SD=3.9) but overall concentrations of gelatinous zooplankton (excluding siphonophores) did (Pseudo-F=6.988; $P=0.001$ ). Overall concentrations were lowest in the $E A C$ jet, shelf waters and the shelf 
break upwelling; and greatest in the frontal eddy and the Tasman Sea cyclonic eddy during the third time sampled (Fig. 2).

Assemblages of gelatinous zooplankton varied among oceanographic features (PERMANOVA Pseudo$\mathrm{F}=6.3392 ; P=0.001$; Fig. 3). Pairwise comparisons indicated that assemblages did not differ between the two EAC locations, the two shelf locations and that the shelf break upwelling did not differ from either of the shelf locations or the Tasman Sea cyclonic eddy during the second time sampled (Supplementary Table 1). The Tasman Sea cyclonic eddy during the second time sampled was also similar to Shelf-1. During the third time sampled, the Tasman Sea cyclonic eddy differed to all other features, except the frontal eddy and the Tasman Sea cyclonic eddy during the second time sampled. Distance based linear modelling (DistLM) revealed that variation in gelatinous zooplankton assemblages was best explained by a combination of salinity, SST and bathymetric depth, which together explained approximately $31 \%$ of the variation in gelatinous zooplankton assemblages among oceanographic features (Table 2; Fig. 3).

SIMPER analyses indicated that dissimilarity among oceanographic features was mainly driven by aggregate and solitary forms of Salpa fusiformis and Thalia democratica, aggregate stages of Soestia zonaria and Traustedtia multitentaculata, doliolids and Pyrosoma atlanticum and the hydrozoan Eutima sp. (Supplementary Table 1). Concentrations of all these taxa varied greatly among oceanographic features (Table 3). Most notably, in the Tasman Sea cyclonic eddy, aggregates of Salpa fusiformis increased 6-fold and concentrations of solitaries doubled over the eight days it was sampled. By the last time sampled, concentrations of $S$. fusiformis aggregates in the Tasman Sea cyclonic eddy were more than five times greater than in any other oceanographic feature. Aggregates and solitaries of $S$. fusiformis were least abundant in the EAC locations and solitaries were also scarce in the shelf break upwelling, frontal eddy and over the shelf. Concentrations of $T$. democratica were highly variable and solitaries were more common than aggregates in most oceanographic features (Fig. 4b). Solitaries were most concentrated in shelf waters, within the frontal eddy and during the first two times the Tasman Sea cyclonic eddy was sampled. Like $S$. fusiformis, aggregates and solitaries of $T$. democratica were scarce in the EAC jet and shelf break upwelling. Aggregates of $S$. zonaria occurred in all oceanographic features, except the frontal eddy, in relatively small numbers but were most concentrated in the Tasman Sea cyclonic eddy during the third time sampled, in the shelf break upwelling and at Shelf-2 (Fig. 4c). Aggregates of T. multitentaculata (Fig. 4d) were absent in shelf waters and the shelf break upwelling and only occurred in notable but small numbers $\left(\sim 0.013\right.$ individuals $\left.\mathrm{m}^{-3}\right)$ in the Tasman Sea cyclonic eddy during the third time sampled. Pyrosoma atlanticum tended to be most abundant in the EAC Jet (Fig. 4e) whilst doliolids (Fig. 4f) and the hydrozoan Eutima sp. (Fig. 4g) were only abundant in the frontal eddy.

In the Tasman Sea cyclonic eddy, concentrations of aggregates of S. fusiformis, Soestia zonaria and Traustedtia multentaculata increased 7-16 fold over the eight days the eddy was sampled. The average ratio of aggregates to solitaries of $S$. fusiformis (an index of production) increased from an average of 2.6 ( $\pm 2.13 \mathrm{SD}$ ) to 10.3 ( $\pm 6.20 \mathrm{SD}$ ) between days 1 and 8 but ratios were highly variable among replicate tows. The production index for the Tasman Sea cyclonic eddy was inversely related to chl $a$ concentrations by the function Ln (Aggregates/Solitaries) = -1.245 Ln Chl - $0.8\left(r^{2}=0.34 ; P=0.005 ;\right.$ Fig. 5). 
Assemblages of siphonophores varied among oceanographic features (PERMANOVA Pseudo $F=2.178$; $P=0.001$; Fig. 6). The siphonophore assemblage at EAC-1 differed to all other locations except for EAC-2 and the two shelf locations (Supplementary Table 2). Differences were largely driven by the frequent occurrence of Hippopodius hippopus within the EAC jet. Siphonophore assemblages at the two shelf sites could not be distinguished from any other oceanographic features (Supplementary Table 2).

Concentrations of zooplankton, as measured by the LOPC, varied among features (Pseudo- $\mathrm{F}=2.9906$; $\mathrm{P}=0.006$ ). Concentrations were greatest at $\mathrm{EAC}-2$, the shelf break upwelling, frontal eddy and the Tasman Sea cyclonic eddy during the first two times sampled. Notably, concentrations halved between the first and last time the Tasman Sea cyclonic eddy was sampled.

\section{Discussion}

The distinctive oceanographic features in the intensification zone of the EAC hosted a diverse and varying community of gelatinous zooplankton. Taxon richness did not vary among oceanographic features, but the abundance and structure of the gelatinous zooplankton communities were influenced by the type of water mass. Most notably, our results confirmed that cold-core eddies are important for production of gelatinous zooplankton (sensu Everett et al. 2011; Henschke et al. 2019), even though concentrations of gelatinous zooplankton in these eddies were orders of magnitude less than have been reported in some cold-core eddies south of the EAC separation zone (e.g. Everett et al. 2011; Henschke et al. 2011, 2014).

The greatest concentrations of gelatinous zooplankton occurred in the frontal eddy and the Tasman Sea cyclonic eddy during the third time sampled, but the community structure of the two eddies differed. The more oceanic Tasman Sea cyclonic eddy was dominated by solitary and aggregate stages of Salpa fusiformis, whereas doliolids were the most common gelatinous zooplankton in the entrained shelf water of the frontal eddy. These differences in community structure reflect the origins of the eddies and differences in the in-situ production of gelatinous zooplankton within each eddy.

The Tasman Sea cyclonic eddy was approximately one month old when first sampled and it was sampled three times over eight days. Trends of increasing abundances of both solitary and aggregate stages of $S$. fusiformis, with increasing temperature and decreasing chl a were observed. S. fusiformis is one of the most widely distributed salps and occurs from $50^{\circ} \mathrm{N}$ to $45^{\circ} \mathrm{S}$ in the Pacific Ocean (van Soest 1974). The abundances we measured during the third time sampled ( 0.3 solitaries $\mathrm{m}^{-3}$ and $\sim 2.8$ aggregates $\mathrm{m}^{-3}$ ) were comparable to those reported in the Humboldt Current (Pagés et al. 2001) but were much smaller than at some sites in the southern Yellow Sea (1.3 solitaries and 67.6 aggregates $\mathrm{m}^{-3}$; (Liu et al. 2012) and Mediterranean Sea (>1000 $\mathrm{m}^{-3}$; (Granata et al. 2020). A similar inverse relationship between S. fusiformis and chl a was observed off the Mejillones Peninsula, Chile (Pagés et al. 2001). In that region, $S$. fusiformis only occurred at stations with intermediate concentrations of chl a $(\sim 0.4-0.7 \mu \mathrm{g}$ $\left.\mathrm{m}^{-3}\right)$ and were absent in upwelling areas where chl a concentrations were high $\left(\sim 1.2-1.6 \mu \mathrm{g} \mathrm{m}^{-3}\right)$. Potential clogging of the salps' feeding structures at high particle loads (Andersen 1985) was proposed to explain 
the relationship (Pagés et al. 2001). The chl a concentrations measured in our study never attained the high concentrations observed by Pagés et al. (2001) but it is feasible that particle concentrations in the Tasman Sea cyclonic eddy were sufficiently high to limit production of $S$. fusiformis when the eddy was first sampled but diminished as the eddy decayed to levels where the $S$. fusiformis population could thrive. The quadrupling in numbers of $S$. fusiformis observed over eight days is consistent with modelled rates of population growth for this species (Braconnot et al. 1988).

Salps are voracious consumers of phytoplankton (Madin and Deibel 1998) but the inverse relationship between $S$. fusiformis and chl $a$ in the Tasman Sea cyclonic eddy was unlikely to have resulted from the salps depleting the standing stock of phytoplankton. Using measured clearance rates of $S$. fusiformis (Andersen 1985) and conservatively assuming large sizes for the solitaries (100 mm) and aggregates (10 $\mathrm{mm}$ ) we sampled, the maximum amount of water the combined life stages in each $\mathrm{m}^{3}$ could have filtered in 24 hours was $~ 42$ litres or only $4.2 \%$ of the water available. Grazing by non-gelatinous zooplankton may have depleted the phytoplankton but concentrations of zooplankton decreased over time in the Tasman Sea cyclonic eddy, which is inconsistent with grazing promoting zooplankton production. Instead, the reduction in chl $a$ and zooplankton may reflect dilution as the eddy became flooded with EAC water as it decayed. Indeed, the SST of the eddy increased $>0.6^{\circ} \mathrm{C}$ over the 8 days sampled, consistent with EAC surface water impinging into the core of the eddy. Rapid production of $S$. fusiformis however, may have masked the effect of dilution on the populations of the salp.

The frontal eddy was much younger than the Tasman Sea cyclonic eddy and formed only about six-days prior to sampling from shear generated when the western edge of the EAC intercepted Fraser Island. This eddy entrained shelf water and contained large abundances of doliolids, and the hydrozoan leptomedusa Eutima sp and the salp Thalia democratica were also common. All three of these taxa are common in coastal waters (Kramp 1968; Greenwood 1980; Deibel 1985; Zeldis et al. 1995), and their occurrences were consistent with the frontal eddy having entrained water from the shelf. Thalia democratica has astounding reproductive capacities and growth rates (Heron and Benham 1984; Henschke et al. 2014) and populations can increase quickly when food is abundant (Henschke et al. 2011; 2014). The frontal eddy, however, was relatively young and although it was cooler than surrounding waters, indicating the upwelling of deep water that is typically rich in nutrients, chl a concentrations were lower than in the shelf break upwelling and even the EAC jet, indicating that primary production was not enhanced in the eddy at the time sampled. Sometimes, there can be a lag of $~ 14$ days before upwelled nutrients translates into increased secondary production (Baird et al. 2006) and concentrations of Thalia democratica remained $>5$ orders of magnitude less than the extreme abundances (5003 individuals $\mathrm{m}^{-3}$ ) reported in a cold core eddy in the southern EAC eddy field (Everett et al. 2011).

The EAC jet supported fewest gelatinous zooplankton but was distinguished by containing 2-10 times more pyrosome colonies (Pyrosoma atlanticum) than the other oceanographic features sampled. Numbers of pyrosome colonies in the EAC jet exceeded, by an order of magnitude, those reported by Henschke et al. (2019) in a cold core eddy south of the EAC separation zone. The colonies we sampled, however, were much smaller (most $<20 \mathrm{~mm}$ versus mean of $107 \mathrm{~mm}$ ) and the overall biomass of 
pyrosomes would have been much smaller than those reported by Henschke et al. (2019). Like other thaliaceans, pyrosomes are efficient phytoplankton grazers, consuming up to $95 \%$ of the daily phytoplankton standing stock (Henschke et al 2019). When phytoplankton is abundant (e.g. chl a 0.4-1 $\mu \mathrm{g} \mathrm{L}^{-1}$ ), efficient grazing promotes extreme growth rates; equivalent to $30 \%$ body $\mathrm{C} \mathrm{d}^{-1}$; (Andersen and Sardou 1994; Henschke et al 2019). Given the relatively low concentrations of chl a observed across all locations in our study, growth of pyrosome colonies in the EAC jet, may have been limited by the availability of phytoplankton.

Shelf waters are typically distinguished by being cooler and more saline than offshore waters (unless in the vicinity of river plumes). At the time sampled, however, the shelf locations were flooded by a coastal intrusion of the EAC and were $>0.5{ }^{\circ} \mathrm{C}$ warmer than at the start of the cruise. The EAC intrusion extended to a depth of approximately $25 \mathrm{~m}$ whilst the bongo net sampled to an average depth of $42 \mathrm{~m}$ at both shelf locations. Consequently, our oblique tows over the shelf sampled a mixture of shelf and EAC water. The shelf locations similarly contained a mixture of taxa, some of which are common in inshore waters (e.g. Thalia democratica, Eutima sp.; Greenwood 1980; Deibel 1985). Notably, however, the siphonophore communities of the shelf locations were indistinguishable from any of the other oceanographic features sampled further offshore, perhaps reflecting the mixing of different water masses over the shelf.

The shelf break upwelling was the coolest and most saline feature sampled, indicating strong upwelling of deep water from the slope. This was a transient feature that appeared only 1-2 days prior to sampling and rapidly disappeared. High concentrations of nutrients in upwelled water typically facilitates primary production but chl a concentrations in the shelf break upwelling were comparable to those at EAC-1 and Shelf-2, indicating that primary production had had insufficient time to substantially increase. Concomitantly, the gelatinous zooplankton community was also depauperate and comprised mainly salps, mostly the ubiquitous Salpa fusiformis. Hence this transient upwelling feature had minimal influence on gelatinous zooplankton production.

Diel vertical migration is a common behaviour of many gelatinous zooplankton. Indeed, some taxa, such as pyrosomes (Andersen \& Sardou 1994; Henschke et al. 2019) and salps can migrate 100s of metres vertically (e.g. Wiebe et al. 1979) and are typically more abundant in surface waters at night. Temporal variation in the vertical distribution of taxa has the potential to confound interpretation of their spatial distributions in surface waters, if the surface waters are sampled at different times. Throughout the voyage, sampling commenced at least an hour after sunset and concluded more than one hour before sunrise, minimising any confounding due to variable vertical distributions.

\section{Conclusion}

The mesoscale oceanographic features of the intensification zone of the EAC supported diverse and differing gelatinous communities. Notably, cyclonic (upwelling) eddies promoted production of gelatinous zooplankton, although overall abundances of gelatinous zooplankton were much lower than sometimes observed in the cyclonic eddies of the EAC separation zone. Understanding the dynamics of 
gelatinous zooplankton populations is important, given they are now recognised as both important prey (Hays et al. 2018) and predators in marine food webs. Moreover, the focus on this region at the tropical/temperate boundary is critical given that it is at the forefront of potential range expansions of tropical taxa.

\section{Declarations}

\section{ACKNOWLEDGEMENTS}

We sincerely thank the Marine National Facility and the superb crew aboard RV Investigator for enabling this project, the financial support of the Sydney Institute of Marine Science, the UNSW Centre for Marine Science \& Innovation, and the Integrated Marine Observing System. Particular thanks extend to the chief scientist B. Sloyan and C. Chapman. We thank M. Caley, C. Cao, M. Langley, B. Lui, A. Puckeridge for assistance with collecting and sorting samples.

Funding: not applicable

Conflicts of interest/Competing interests: nil

Availability of data and material: Available from author on request

Code availability: not applicable

\section{References}

Acuna JL, Lopez-Urrutia A, Colin S (2011) Faking Giants: The Evolution of High Prey Clearance Rates in Jellyfishes. Science 333: 1627-1629 doi 10.1126/science.1205134

Andersen V (1985) Filtration and ingestion rates of Salpa fusiformis Cuvier (Tunicata, Thaliacea). Effects of size, individual weight and algal concentration. J Exp Mar Biol Ecol 87: 13-29 doi 10.1016/00220981(85)90188-1

Andersen V, Sardou J (1994) Pyrosoma atlanticum (Tunicata, Thaliacea). Diel migration and vertical distribution as a function of colony size. J Plankton Res 16: 337-349 doi 10.1093/plankt/16.4.337

Anderson MJ (2001) Permutation tests for univariate or multivariate analysis of variance and regression. Can J Fish Aquat Sci 58: 626-639 doi 10.1139/cjfas-58-3-626

Armbrecht LH, Roughan M, Rossi V, Schaeffer A, Davies PL, Waite AM, Armand LK (2014) Phytoplankton composition under contrasting oceanographic conditions: Upwelling and downwelling (Eastern Australia). Cont Shelf Res 75: 54-67 doi 10.1016/j.csr.2013.11.024

Armbrecht LH, Schaeffer A, Roughan M, Armand LK (2015) Interactions between seasonality and oceanic forcing drive the phytoplankton variability in the tropical-temperate transition zone (similar to 30 degrees 
S) of Eastern Australia. J Mar Sys 144: 92-106 doi 10.1016/j.jmarsys.2014.11.008

Baird ME, Timko PG, Suthers IM, Middleton JH (2006) Coupled physical-biological modelling study of the East Australian Current with idealised wind forcing. Part 1: Biological model intercomparison. J Mar Sys 59: 249-270 doi 10.1016/j.jmarsys.2005.09.005

Braconnot JC, Choe SM, Nival P (1988) Growth and development of Salpa fusiformis Cuvier (Tunicata, Thaliacea). Annales De L Institut Oceanographique 64: 101-114

Condon RH, Steinberg DK, del Giorgio PA, Bouvier TC, Bronk DA, Graham WM, Ducklow HW (2011) Jellyfish blooms result in a major microbial respiratory sink of carbon in marine systems. Proc Natl Acad Sci USA 108: 10225-10230 doi 10.1073/pnas.1015782108

Deibel D (1985) Blooms of the pelagic tunicate, Dolioletta gengenbaruri: Are they associated with Gulf Stream frontal eddies? J Mar Res 43: 211-236 doi 10.1357/002224085788437307

Everett JD, Baird ME, Oke PR, Suthers IM (2012) An avenue of eddies: Quantifying the biophysical properties of mesoscale eddies in the Tasman Sea. Geophys Res Lett 39 doi 10.1029/2012gl053091

Everett JD, Baird ME, Roughan M, Suthers IM, Doblin MA (2014) Relative impact of seasonal and oceanographic drivers on surface chlorophyll a along a Western Boundary Current. Prog Oceanogr 120: 340-351 doi 10.1016/j.pocean.2013.10.016

Everett JD, Baird ME, Suthers IM (2011) Three-dimensional structure of a swarm of the salp Thalia democratica within a cold-core eddy off southeast Australia. J Geophy Res-Oceans 116 doi $10.1029 / 2011 \mathrm{jc} 007310$

Foxton P (1966) The distribution and life-history of Salpa thompsoni Foxton with observations on a related species, Salpa gerlachei Foxton. Discov Rep 34: 1-116

Granata A, Bergamasco A, Battaglia P, Milisenda G, Pansera M, Bonanzinga V, Arena G, Andaloro F, Giacobbe S, Greco S, Guglielmo R, Spano N, Zagami G, Guglielmo L (2020) Vertical distribution and diel migration of zooplankton and micronekton in Polcevera submarine canyon of the Ligurian mesopelagic zone (NW Mediterranean Sea). Prog Oceanogr 183 doi 10.1016/j.pocean.2020.102298

Greenwood J (1980) Composition and seasonal variations of zooplankton populations in Moreton Bay, Queensland. Proc R Soc Queensl 91: 85-103

Hays GC, Doyle TK, Houghton JDR (2018) A Paradigm Shift in the Trophic Importance of Jellyfish? Trends Ecol Evol 33: 874-884 doi 10.1016/j.tree.2018.09.001

Henschke N, Everett JD, Doblin MA, Pitt KA, Richardson AJ, Suthers IM (2014) Demography and interannual variability of salp swarms (Thalia democratica). Mar Biol 161: 149-163 doi 10.1007/s00227013-2325-2 
Henschke N, Everett JD, Suthers IM, Smith JA, Hunt BPV, Doblin MA, Taylor MD (2015) Zooplankton trophic niches respond to different water types of the western Tasman Sea: A stable isotope analysis. Deep-Sea Res I-Oceanographic Research Papers 104: 1-8 doi 10.1016/j.dsr.2015.06.010

Henschke N, Pakhomov EA (2018) Latitudinal variations in Salpa thompsoni reproductive fitness. Limnol Oceanogr 9999: 1-10 doi: 10.1002/Ino.11061

Henschke N, Pakhomov EA, Kwong LE, Everett JD, Laiolo L, Coghlan AR, Suthers IM (2019) Large Vertical Migrations of Pyrosoma atlanticum Play an Important Role in Active Carbon Transport. J Geophys ResBiogeosciences 124: 1056-1070 doi 10.1029/2018jg004918

Herman AW, Beanlands B, Phillips EF (2004) The next generation of Optical Plankton Counter: the LaserOPC. J Plankton Res 26: 1135-1145 doi 10.1093/plankt/fbh095

Heron AC, Benham EE (1984) Individual growth rates of salps in three populations. J Plankton Res 6: 811828 doi 10.1093/plankt/6.5.811

Hofmann EE, Powell TM (1998) Environmental variability effects on marine fisheries: Four case histories. Ecol App 8: S23-S32 doi 10.1890/1051-0761(1998)8[s23:Eveomf]2.0.Co;2

IOC, IHO \& BODC (2003) Centenary Edition of the GEBCO Digital Atlas, Published on CD-ROM on Behalf of the Intergovernmental Oceanographic Commission and the International Hydrographic Organization as Part of the General Bathymetric Chart of the Oceans. British Oceanographic Data Centre, Liverpool, UK. Ismail MFA, Ribbe J, Karstensen J, Lemckert C, Lee S, Gustafson J (2017) The Fraser Gyre: A cyclonic eddy off the coast of eastern Australia. Estuar Coast Shelf Sci 192: $72-85$ doi 10.1016/j.ecss.2017.04.031

Liu YQ, Sun S, Zhang GT (2012) Seasonal variation in abundance, diel vertical migration and body size of pelagic tunicate Salpa fusiformis in the Southern Yellow Sea. Chin J Oceanol Limnol 30: 92-104 doi $10.1007 / \mathrm{s} 00343-012-1048-4$

Lucas CH, Jones DOB, Hollyhead CJ, Condon RH, Duarte CM, Graham WM, Robinson KL, Pitt KA, Schildhauer M, Regetz J (2014) Gelatinous zooplankton biomass in the global oceans: geographic variation and environmental drivers. Glob Ecol Biogeogr 23: 701-714 doi 10.1111/geb.12169

Luo JY, Condon RH, Stock CA, Duarte CM, Lucas CH, Pitt KA, Cowen RK (2020) Gelatinous ZooplanktonMediated Carbon Flows in the Global Oceans: A Data-Driven Modeling Study. Global Biogeochemical Cycles 34 doi 10.1029/2020gb006704

Madin L, Deibel D (1998) Feeding and energetics of Thaliacea. In: Bone Q (ed) The biology of pelagic tunicates. Oxford University Press, Oxford, pp 81-103

Malan N, Archer M, Roughan M, Cetina-Heredia P, Hemming M, Rocha C, Schaeffer A, Suthers I, Queiroz E (2020) Eddy-Driven Cross-Shelf Transport in the East Australian Current Separation Zone. J Geophys Res- 
Matis PA, Figueira WF, Suthers IM, Humphries J, Miskiewicz A, Coleman RA, Kelaher BP, Taylor MD (2014) Cyclonic entrainment? The ichthyoplankton attributes of three major water mass types generated by the separation of the East Australian Current. ICES J Mar Sci 71: 1696-1705 doi 10.1093/icesjms/fsu062

Mullaney TJ, Miskiewicz AG, Baird ME, Burns PTP, Suthers IM (2011) Entrainment of larval fish assemblages from the inner shelf into the East Australian Current and into the western Tasman Front. Fish Oceanogr 20: 434-447 doi 10.1111/j.1365-2419.2011.00594.x

Oke PR, Roughan M, Cetina-Heredia P, Pilo GS, Ridgway KR, Rykova T, Archer MR, Coleman RC, Kerry CG, Rocha C, Schaeffer A, Vitarelli E (2019) Revisiting the circulation of the East Australian Current: Its path, separation, and eddy field. Prog Oceanogr 176 doi 10.1016/j.pocean.2019.102139

Pagés F, Gonzalez HE, Ramon M, Sobarzo M, Gili J-M (2001) Gelatinous zooplankton assemblages associated with water masses in the Humboldt Current System, and potential predatory impact by Bassia bassensis (Siphonophora: Calycophorae). Mar Ecol-Prog Ser 210: 13-24

Pitt KA, Duarte CM, Lucas CH, Sutherland KR, Condon RH, Mianzan H, Purcell JE, Robinson KL, Uye SI (2013) Jellyfish Body Plans Provide Allometric Advantages beyond Low Carbon Content. PLoS One 8 doi 10.1371/journal.pone.0072683

Revill AT, Young JW, Lansdell M (2009) Stable isotopic evidence for trophic groupings and bioregionalization of predators and their prey in oceanic waters off eastern Australia. Mar Biol 156: 12411253 doi 10.1007/s00227-009-1166-5

Riandey V, Champalbert G, Carlotti F, Taupier-Letage I, Thibault-Botha D (2005) Zooplankton distribution related to the hydrodynamic features in the Algerian Basin (western Mediterranean Sea) in summer 1997. Deep-Sea Res Part I-Oceanographic Research Papers 52: 2029-2048 doi 10.1016/j.dsr.2005.06.004

Ribbe J, Brieva D (2016) A western boundary current eddy characterisation study. Estuar Coast Shelf Sci 183: 203-212 doi 10.1016/j.ecss.2016.10.036

Ribbe J, Toaspern L, Wolff JO, Ismail MFA (2018) Frontal eddies along a western boundary current. Cont Shelf Res 165: 51-59 doi 10.1016/j.csr.2018.06.007

Ridgway KR, Dunn JR (2003) Mesoscale structure of the mean East Australian Current System and its relationship with topography. Prog Oceanogr 56: 189-222 doi 10.1016/s0079-6611(03)00004-1

Roesler C, Uitz J, Claustre H, Boss E, Xing XG, Organelli E, Briggs N, Bricaud A, Schmechtig C, Poteau A, D'Ortenzio F, Ras J, Drapeau S, Haentjens N, Barbieux M (2017) Recommendations for obtaining unbiased chlorophyll estimates from in situ chlorophyll fluorometers: A global analysis of WET Labs ECO sensors. Limnol Oceanogr-Methods 15: 572-585 doi 10.1002/lom3.10185 
Sloyan BM, Ridgway KR, Cowley R (2016) The East Australian Current and Property Transport at 27 degrees S from 2012 to 2013. J Phys Oceanogr 46: 993-1008 doi 10.1175/jpo-d-15-0052.1

Sprintall J, Roemmich D, Stanton B, Bailey R (1995) Regional climate variability and ocean heat transport in the southwest Pacific Ocean. J Geophys Res-Oceans 100: 15865-15871 doi 10.1029/95jc01664

Suthers IM, Everett JD, Roughan M, Young JW, Oke PR, Condie SA, Hartog JR, Hobday AJ, Thompson PA, Ridgway K, Baird ME, Hassler CS, Brassington GB, Byrne M, Holbrook NJ, Malcolm HA (2011) The strengthening East Australian Current, its eddies and biological effects - an introduction and overview. Deep-Sea Res Part li-Topical Studies in Oceanography 58: 538-546 doi 10.1016/j.dsr2.2010.09.029 van Soest R (1974) A revision of the genera Salpa Forskål, 1775, Pegea Savigny, 1816 and Ritteriella Metcalf, 1919 (Tunicata, Thaliacea). Beaufortia 22(293): 153-191

Wiebe PH, Madin LP, Haury LR, Harbison GR, Philbin LM (1979) Diel vertical migration by Salpa aspersa and its potential for large-scale particulate organic matter transport to the deep-sea. Mar Biol 53: 249-255

Wright RM LQC, Buitenhuis E, Pitois S, Gibbons MJ (2021) Role of jellyfish in the plankton ecosystem revealed using a global oceano biogeochemical model. Biogeosci 18: 1291-1320 doi https://doi.org/10.5194/bg-18-1291-2021

Young JW, Hobday AJ, Campbell RA, Kloser RJ, Bonham PI, Clementson LA, Lansdell MJ (2011) The biological oceanography of the East Australian Current and surrounding waters in relation to tuna and billfish catches off eastern Australia. Deep-Sea Res Part li-Topical Studies in Oceanography 58: 720-733 doi 10.1016/j.dsr2.2010.10.005

Zeldis JR, Davis CS, James MR, Ballara SL, Booth WE, Hoe Chang F (1995) Salp grazing: effects on phytoplankton abundance, vertical distribution and taxonomic composition in a coastal habitat. Mar Ecol-Prog Ser 126: 267-283

\section{Tables}

Table 1. Sampling details and hydrographic characteristics of the oceanographic features sampled. Values are mean $\pm S D$. $\mathbf{N}=$ number of net tows, $T e m p=$ temperature. 


\begin{tabular}{|llllll|}
\hline Oceanographic Feature & Date sampled & $\mathrm{N}$ & Temp $\left({ }^{\circ} \mathrm{C}\right)$ & Salinity & Chl $a\left(\mu \mathrm{g} \mathrm{L}^{-1}\right)$ \\
\hline EAC-1 & $11 / 9 / 2019$ & 7 & $21.82 \pm 0.03$ & $35.66 \pm 0.01$ & $0.24 \pm 0.029$ \\
\hline EAC-2 & $13 / 9 / 2013$ & 7 & $21.64 \pm 0.06$ & $35.68 \pm 0.01$ & $0.12 \pm 0.04$ \\
\hline Tasman Sea Cyclonic Eddy & $15 / 9 / 2019$ & 10 & $21.17 \pm 0.30$ & $35.60 \pm 0.01$ & $0.13 \pm 0.05$ \\
\hline Tasman Sea Cyclonic Eddy & $20 / 9 / 2019$ & 6 & $21.62 \pm 0.21$ & $35.60 \pm 0.01$ & $0.08 \pm 0.03$ \\
\hline Tasman Sea Cyclonic Eddy & $23 / 9 / 2019$ & 6 & $21.78 \pm 0.16$ & $35.61 \pm 0.03$ & $0.06 \pm 0$ \\
\hline Shelf Break Upwelling & $16 / 9 / 2019$ & 6 & $20.50 \pm 0.09$ & $35.72 \pm 0.01$ & $0.22 \pm 0.07$ \\
\hline Frontal Eddy & $18 / 9 / 2019$ & 6 & $21.24 \pm 0.10$ & $35.59 \pm 0.01$ & $0.12 \pm 0.03$ \\
\hline Shelf-1 & $22 / 9 / 2019$ & 8 & $21.66 \pm 0.21$ & $35.62 \pm 0.01$ & $0.19 \pm 0.06$ \\
\hline Shelf-2 & $26 \& 27 / 9 / 2019$ & 6 & $21.39 \pm 0.26$ & $35.64 \pm 0.01$ & $0.22 \pm 0.06$ \\
\hline
\end{tabular}

Table 2. Results of DistLM analyses of the amount of variation in gelatinous zooplankton assemblages explained by environmental variables.

\begin{tabular}{|llll|}
\hline Variable & Pseudo-F & $P$ & \% of variation explained \\
\hline Salinity & 11.7170 & 0.001 & 16.11 \\
\hline SST & 9.0775 & 0.001 & 11.02 \\
\hline Depth & 3.069 & 0.008 & 3.60 \\
\hline
\end{tabular}

Table 3. Results of one-way PERMANOVAs comparing concentrations of individual taxa among oceanographic features.

\begin{tabular}{|lll|}
\hline Taxon & Pseudo-F & $P$ \\
\hline Salpa fusiformis (aggregate) & 4.1325 & 0.001 \\
\hline Salpa fusiformis (solitary) & 4.2173 & 0.001 \\
\hline Thalia democratica (aggregate) & 3.4065 & 0.003 \\
\hline Thalia democratica (solitary) & 2.1915 & 0.013 \\
\hline Traustedtia multitentaculata (aggregate) & 3.9536 & 0.002 \\
\hline Doliolidae & 3.1026 & 0.005 \\
\hline Soestia zonaria (aggregate) & 3.6636 & 0.001 \\
\hline Pyrosoma cf atlanticum colonies & 3.0247 & 0.005 \\
\hline Eutima sp. & 3.3446 & 0.006 \\
\hline
\end{tabular}




\section{Figures}

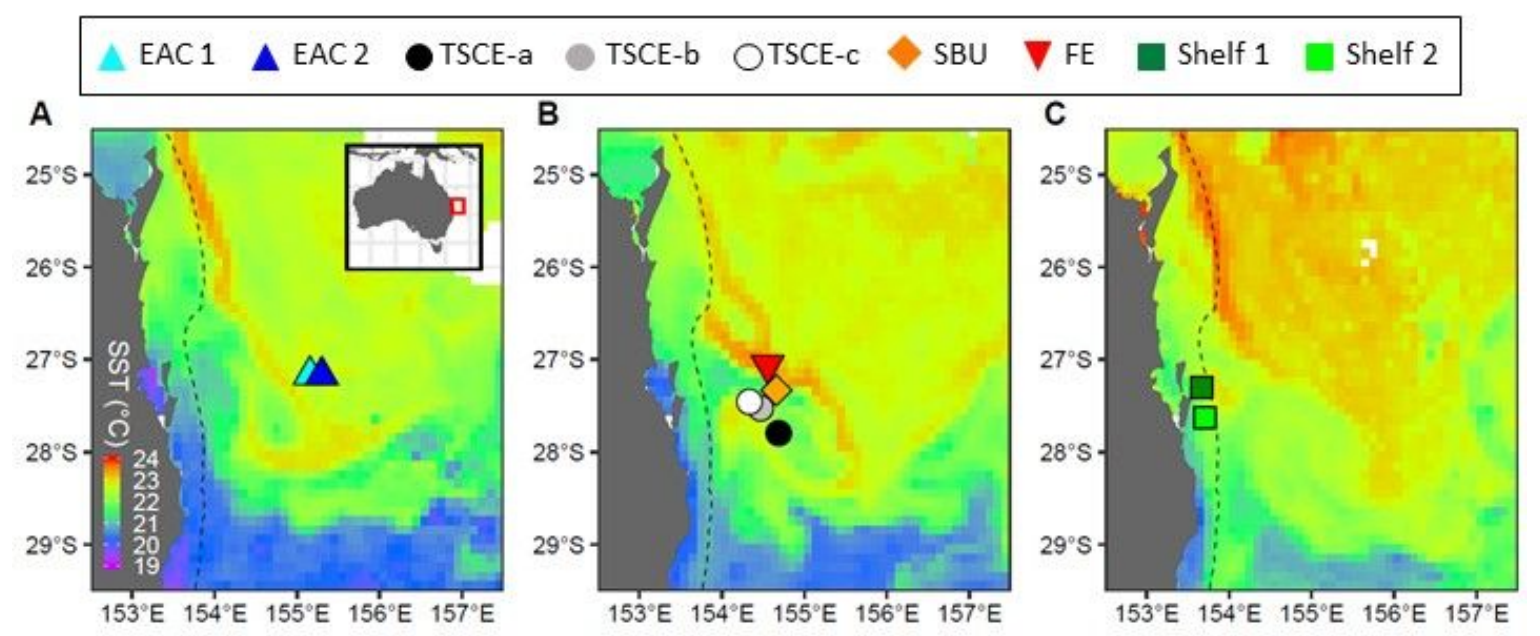

\section{Figure 1}

Mean $( \pm S D)$ concentrations of gelatinous zooplankton (excluding siphonophores) among oceanographic features. Thaliaceans comprised $98.9 \%$ of all gelatinous zooplankton. EAC=East Australia Current; TSCE=Tasman Sea Cyclonic Eddy (sampled three times over eight days; TSCE-a, TSCE-b, TSCE-c); 
SBU=Shelf Break Upwelling; FE=Frontal Eddy. Letters above bars indicate similarity (e.g. AA) or differences (e.g. AB) between oceanographic features.

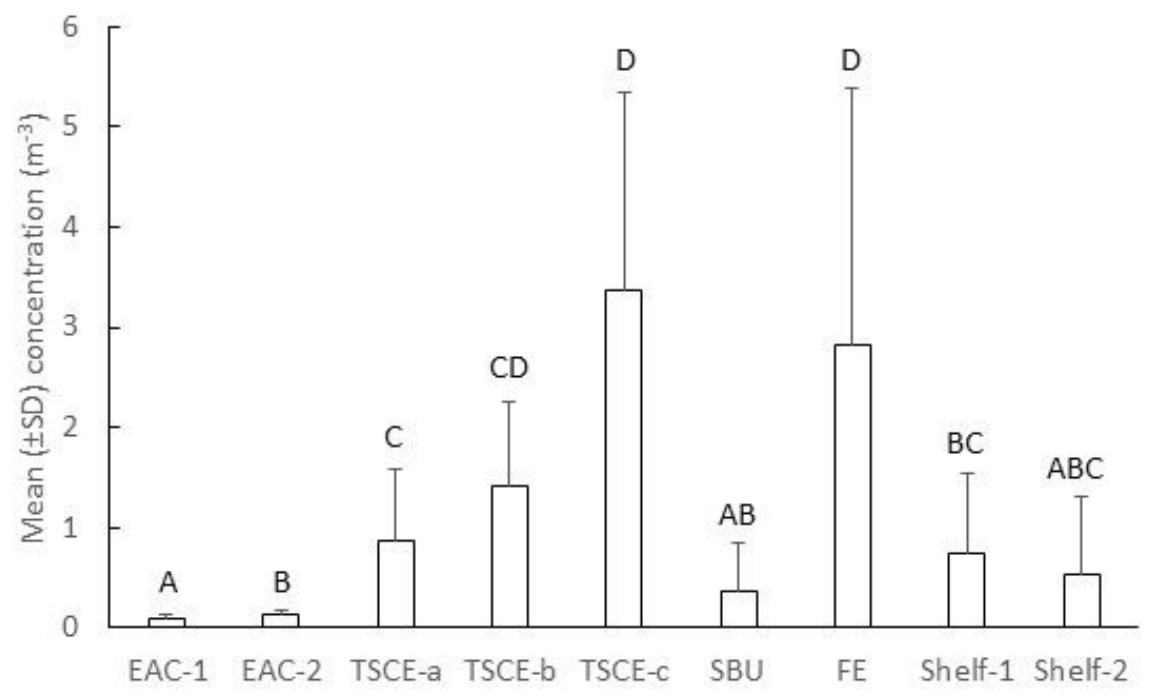

Figure 2

Mean ( \pm SD) concentrations of gelatinous zooplankton (excluding siphonophores) among oceanographic features. Thaliaceans comprised $98.9 \%$ of all gelatinous zooplankton. EAC=East Australia Current; TSCE=Tasman Sea Cyclonic Eddy (sampled three times over eight days; TSCE-a, TSCE-b, TSCE-c); 
$\mathrm{SBU}=$ Shelf Break Upwelling; FE=Frontal Eddy. Letters above bars indicate similarity (e.g. AA) or differences (e.g. AB) between oceanographic features.

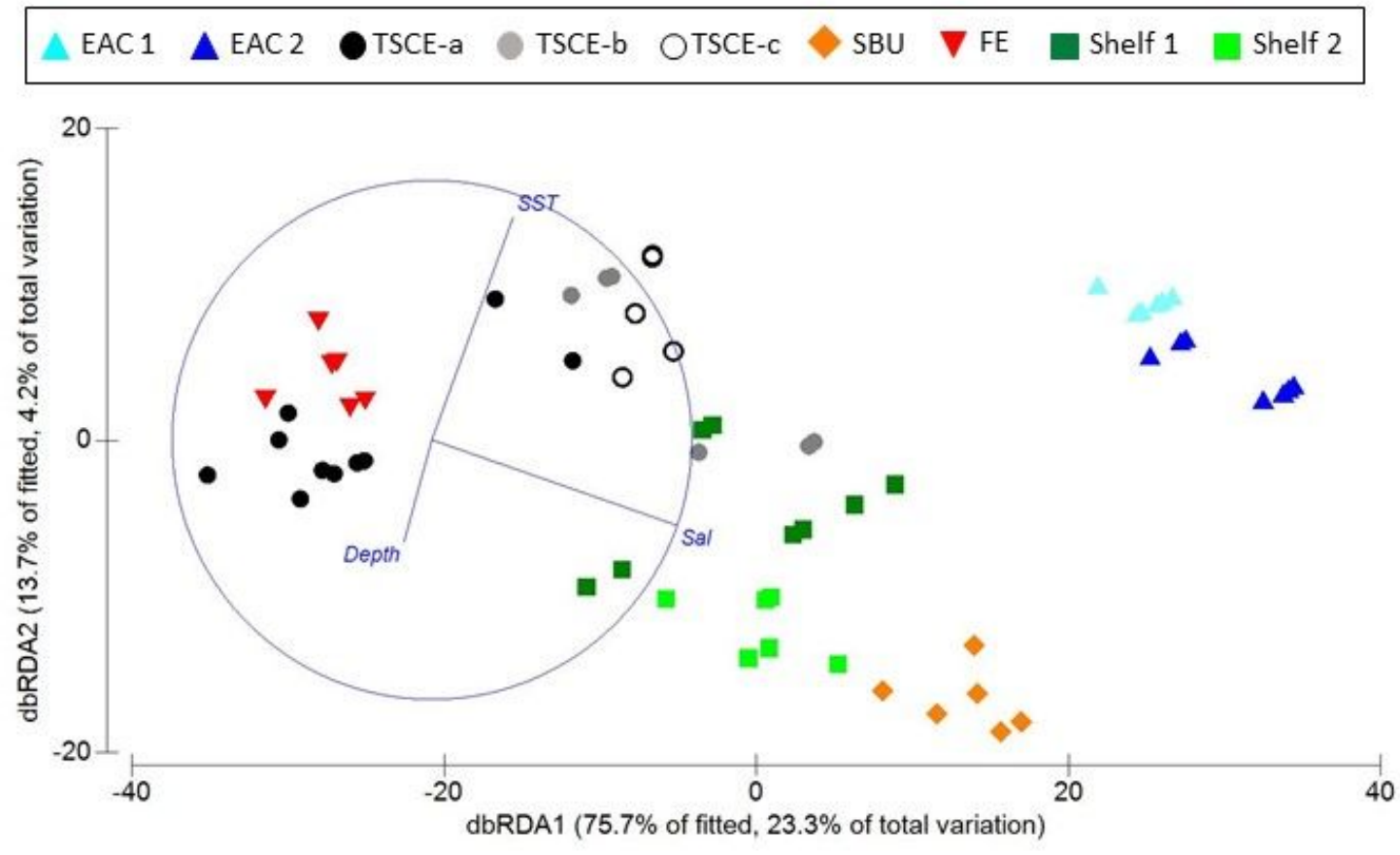

Figure 3

$\mathrm{dbRDA}$ ordination of gelatinous zooplankton assemblages and the predictor variables (SST, salinity and bathymetric depth) that explained most of the variability in assemblages among oceanographic features. 
EAC=East Australia Current; TSCE=Tasman Sea Cyclonic Eddy; SBU=Shelf Break Upwelling; FE=Frontal Eddy.
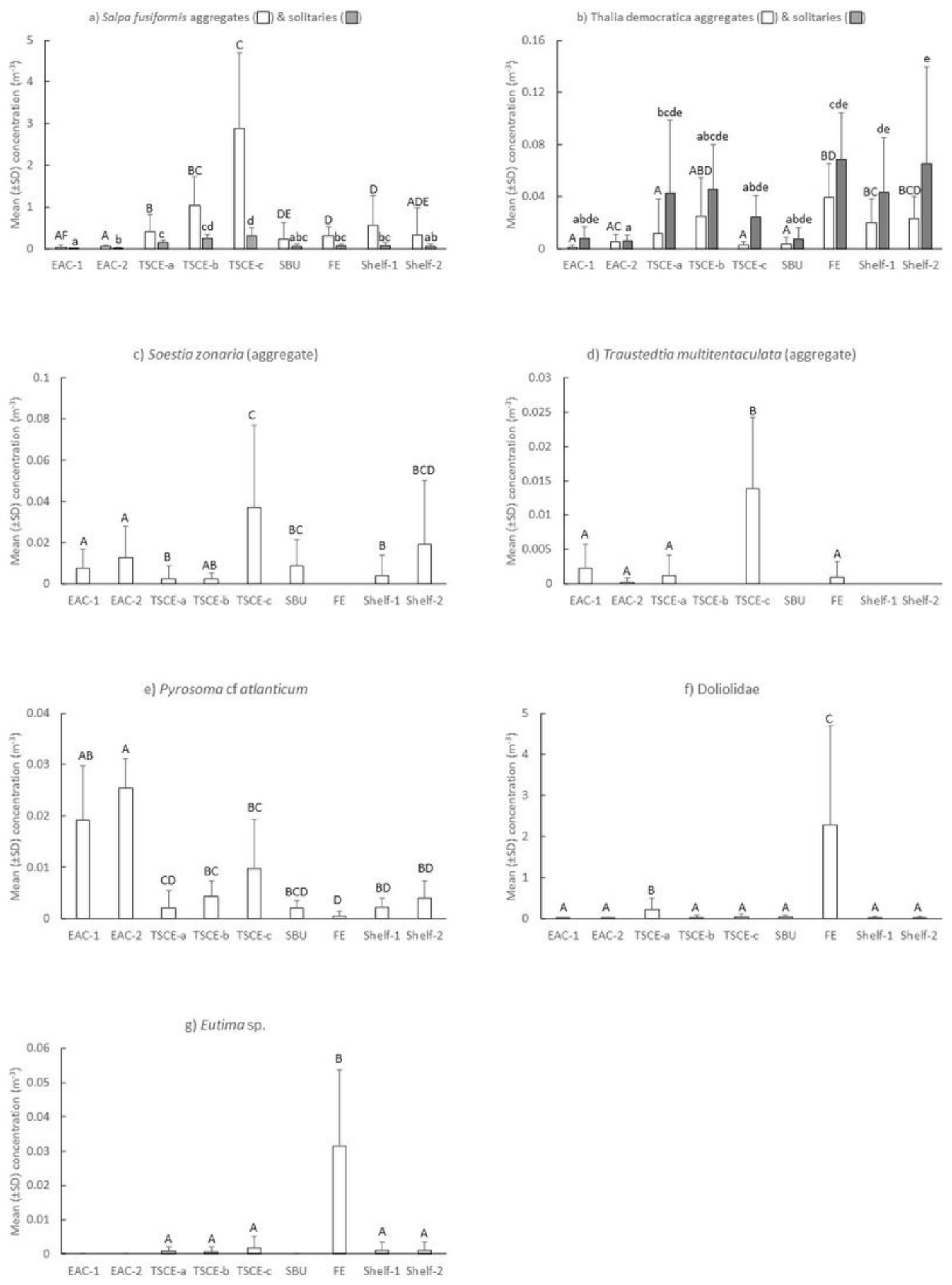

\section{Figure 4}

Mean $( \pm S D)$ abundances of individual taxa (including aggregate and solitary stages of some salps) among oceanographic features. Letters above bars indicate similarity (e.g. AA) or differences (e.g. AB) between oceanographic features. Note different scales on y-axes. 


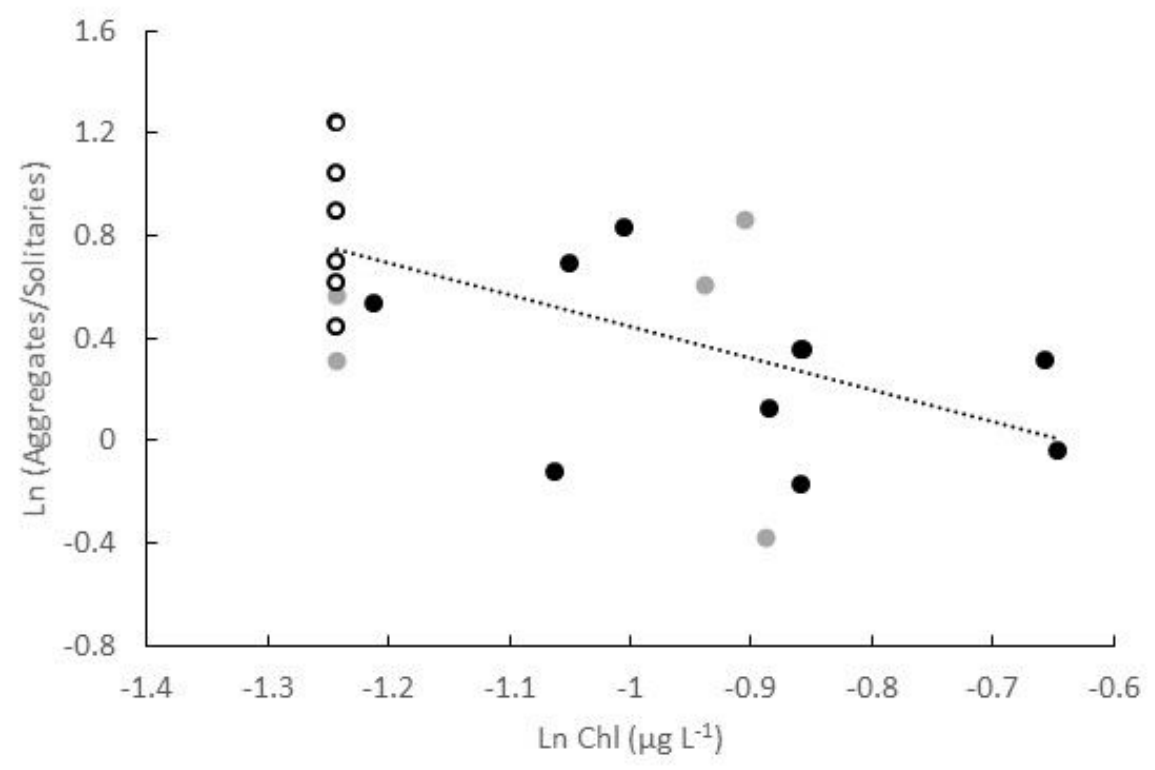

\section{Figure 5}

Relationship between Salpa fusiformis production (aggregates/solitaries) and chl a concentration in the Tasman Sea Cyclonic Eddy during the three times it was sampled $(15 / 9 / 2019=\mathbf{0} ; 20 / 9 / 2019=\mathbf{0}$; $23 / 9 / 2019=0$ ) 


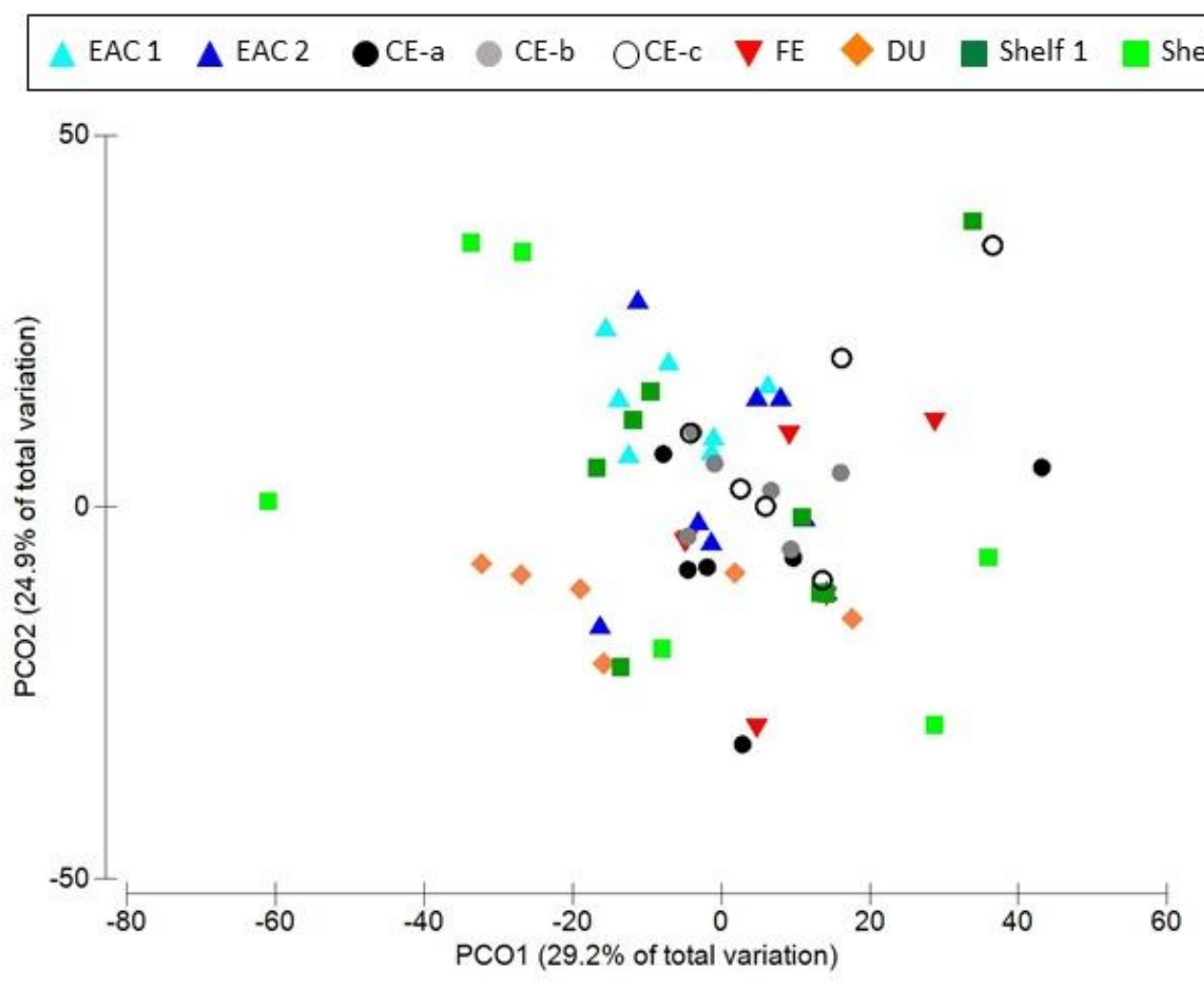

Figure 6

PCO plot of variation in siphonophore assemblages among oceanographic features. 


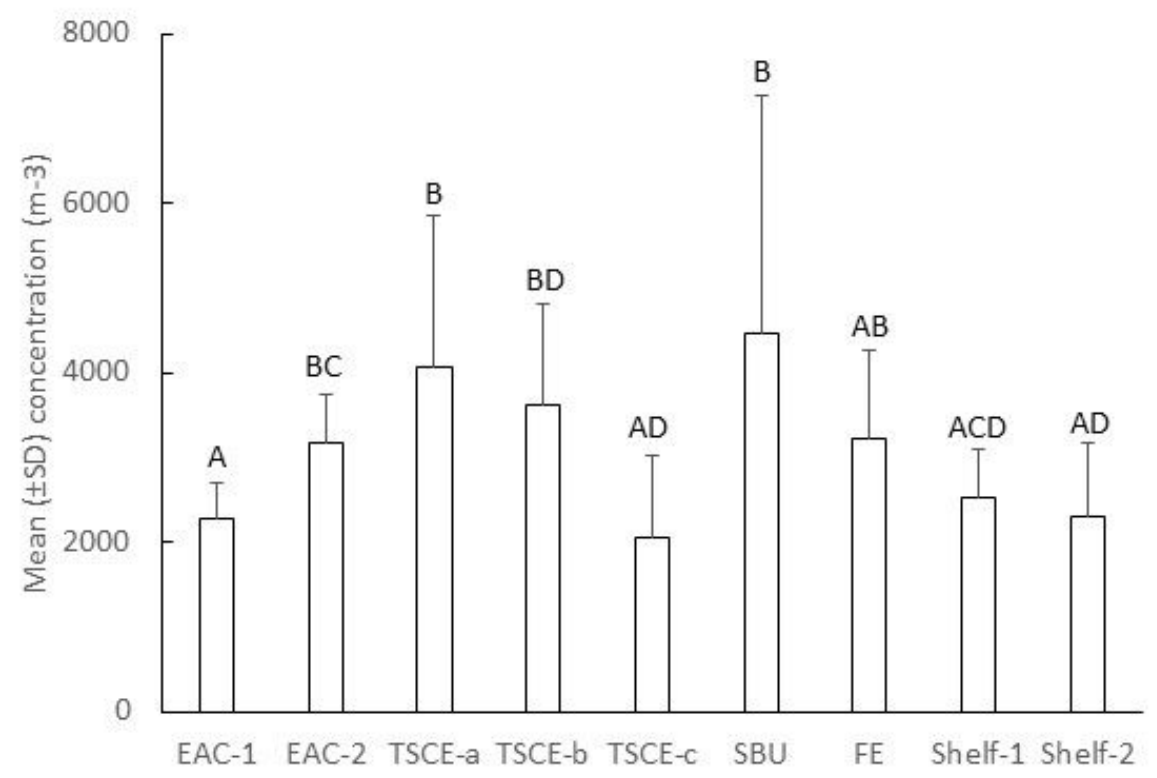

\section{Figure 7}

Mean ( $\pm S D$ ) concentrations of zooplankton (including gelatinous and non-gelatinous taxa) among oceanographic features, counted using the LOPC. EAC=East Australia Current; TSCE=Tasman Sea Cyclonic Eddy (sampled three times over eight days; TSCE-a, TSCE-b, TSCE-c); SBU=Shelf Break Upwelling; FE=Frontal Eddy. Letters above bars indicate similarity (e.g. AA) or differences (e.g. AB) between oceanographic features. 


\section{Supplementary Files}

This is a list of supplementary files associated with this preprint. Click to download.

- SupplementaryTable12.docx 